\section{Acute intracranial hypertension after nalidixic acid administration}

Nalidixic acid (Negram) is an antimicrobial agent widely used in the treatment of urinary tract infection. Some years ago Boréus and Sundström (1967) reported intracranial hypertension in a 6-month-old boy treated with nalidixic acid at the manufacturer's recommended dose. Only a few cases have been reported since, mostly in children treated either with large doses (Fisher, 1967) or for prolonged periods of from 16 days to 6 weeks (Guran, Moriette, and Blanc, 1972; Anderson, Anderson, and Nashold, 1971). 2 babies were recently admitted with the diagnosis of acute intracranial hypertension, both having been treated with nalidixic acid for less than 24 hours.

\section{Case reports}

Case 1. A 6-month-old baby weighing $7 \cdot 2 \mathrm{~kg}$ presented with recurrent urinary tract infections. At the age of 6 weeks a first infection was successfully treated with ampicillin and cephalothin. At 6 months of age a repeat episode of urinary tract infection was treated with nalidixic acid. The prescribed dose was $80 \mathrm{mg} / \mathrm{kg}$ per day (manufacturer's recommended dose: $60 \mathrm{mg} / \mathrm{kg}$ per day). Drug administration was started in the morning. 12 hours later the baby became markedly irritable and presented with vomiting and bulging of the fontanelle. At this time a total dose of $80 \mathrm{mg} / \mathrm{kg}$ nalidixic acid had been administered in 3 divided doses. On admission to hospital he was an afebrile, drowsy, hypotonic baby with marked bulging of the fontanelle. At lumbar puncture, the pressure was $>200 \mathrm{~mm} \mathrm{H}_{2} \mathrm{O}$. CSF was clear, colourless, with normal protein and without cells. Lumbar puncture was followed by an immediate symptomatic improvement. Nalidixic acid was discontinued and within 24 hours the infant's condition was normal. Radioisotopic lumbar cisternography and air encephalography were normal.

Case 2. A 4-month-old boy weighing 7.1 kg presented with otitis media and was treated for 10 days with penicillin. Because of persisting fever, he was admitted to a country hospital and myringotomy was parformed. Urinary tract infection was diagnosed and treatment with nalidixic acid was started. Less than 24 hours later, when the child had received a total dose of 85 $\mathrm{mg} / \mathrm{kg}$ nalidixic acid, given in $\mathbf{4}$ divided doses, irritability and vomiting occurred. Soon after, bulging of the anterior fontanelle was observed. He was referred to us with a diagnosis of acute meningitis. On admission he was afebrile, pale, conscious, and inactive. There was marked bulging of the anterior fontanelle, without other neurological symptoms. Lumbar puncture showed a clear, colourless fluid, with no cells and normal proteins. Pressure was $220 \mathrm{~mm} \mathrm{H}_{2} \mathrm{O}$. After withdrawal of a few $\mathrm{ml} \mathrm{CSF}$, the anterior fontanelle was much softer.
Nalidixic acid was discontinued and 24 hours later the infant's recovery was complete. Urine culture grew Pseudomonas. Gentamicin $1 \mathrm{mg} / \mathrm{kg}$ was given for 10 days with good results.

\section{Comment}

In 2 infants acute intracranial hypertension occurred less than 24 hours after starting therapy with nalidixic acid; symptoms disappeared rapidly after discontinuing drug administration. In neither case was the dose greatly above the manufacturer's recommended dose of $60 \mathrm{mg} / \mathrm{kg}$ per day. Attention is called to the fact that intracranial hypertension can occur acutely, and in the absence of prolonged administration of nalidixic acid, or of significant overdosage.

\section{Summary}

Two infants treated with nalidixic acid for urinary tract infection presented with acute intracranial hypertension. Symptoms appeared during the first 24 hours of treatment when total doses of 80 and 85 $\mathrm{mg} / \mathrm{kg}$, respectively, of nalidixic acid were given. It is concluded that occurrence of intracranial hypertension can be acute, and does not require large doses or prolonged administration of the drug.

\section{REFERENCES}

Anderson, E. E., Anderson, B., and Nashold, B. S. (1971). Childhood complications of nalidixic acid. Fournal of the American Medical Association, 216, 1023.

Boréus, L. O., and Sundström, B. (1967). Intracranial hypertension in a child during treatment with nalidixic acid. British Medical Fournal, $2,744$.

Fisher, O. D. (1967). Nalidixic acid and intracranial hypertension. British Medical fournal, 3, 370.

Guran, P., Moriette, G., and Blanc, A. (1972). Hypertension intracrânienne aiguë et transitoire chez une enfant de 9 ans traitée par l'acide nalidixique. Archives Françaises de Pédiatrie, $29,1107$.

T. Deonna* and J. P. Guignard

Department of Paediatrics, Hôpital Cantonal Universitaire, Lausanne, Switzerland.

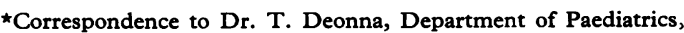
Hôpital Cantonal Universitaire, 1011 Lausanne, Switzerland.

\section{A simple device for applying both CNP and CPAP in new- born infants suffering from respiratory distress syndrome}

The expiratory grunt in newborns with the respiratory distress syndrome (RDS) is caused by expelling air against a partially closed glottis. This 